\title{
Legal Strategy and Effects of California's Zero Emission Vehicle Program
}

\author{
Ju-Yin Chen
}

\begin{abstract}
After surviving industry litigation, California keeps the leading pace to carry on Zero Emission Vehicle program. Even EPA also finds that the California program meets legal requirements regarding the protectiveness of public health and welfare as well as technological feasibility. California's regulatory structure play a key role to meet the program requirements, ensuring that state consumers receive cleaner energy, efficient and a variety of technologies, and modeling to work collaboratively with both public and private partners. Comparing the global regulatory landscape of EV regulatory methodology with California model, we may consider that regulatory and legal strategies are significant tool to meet the goal of reduce GHGs emission.
\end{abstract}

Index Terms-Electric vehicle, zero emission, greenhouse gases, California, regulatory science, legal strategy, legislation.

\section{INTRODUCTION}

California's Zero Emission Vehicle (ZEV) program regulation was first enacted in 1990, and at that time California is the only state adopted ZEV rules as part of Low Emission Vehicle (LEV I) standards affecting emissions from new vehicles under the federal Clean Air Act1963(CAA). The program required that $2 \%$ of the vehicles that large manufacturers produced for sale in California in 1998 had to be ZEVs, increasing to 5\% in 2001 and $10 \%$ in 2003 . Then, a more flexible strategy with a complex credit system set for allowing partial ZEV (PZEV), hybrids, plug-in hybrids and modest numbers of battery-electric and fuel cell vehicles(BEV and FCV). Recently in 2015, according to the California Air Resources Board (CARB), California's zero-emission goal, with the requirement that all new vehicles sold within the state be almost or entirely emissions free by 2030.

Many successes have come out of the regulation, especially, nearly 2 million Californians are driving partial zero and advanced technology partial zero emission vehicles. The program enriches consumers' choice, and provides critical pollution reductions in the near term which are $80 \%$ cleaner than the average 2002 model year car [1].

Due to a lawsuit filed against the Board, a federal district judge issued a preliminary injunction that prohibited the Board from enforcing the 2001 ZEV amendments with respect to the sale of new motor vehicles in model years 2003 or 2004. In order to address the preliminary injunction and better align the program requirements with the status of technology development, CARB staff proposed additional

Manuscript received March 27, 2016; revised July 12, 2016.

Ju-Yin Chen is with Soochow University, Taiwan (e-mail: pio362@yahoo.com.tw). modifications to the ZEV regulation in March 2003. This essay will retrace the history of ZEV regulation in the first place, and continue to discuss the legal strategy and effects from the concerning laws, and finally compare the current policy and legislative of other states in the United States as well as global regulatory landscape. Hopefully, this research may provide some empirical point of views from California for further reform of electric vehicle regulations in the era of sustainable energy.

\section{History OF ZEV LEgAL AND REGULATORY ACTIVITIES}

\section{A. Regulatory Background}

As originally adopted in 1990, the ZEV regulations required that specified percentages of the passenger cars and lightest light-duty trucks produced by each of the seven largest auto manufacturers be ZEVs, starting in 1998. The percentages were 2 percent for the 1998-2000 model years and 5 percent for the 2001-2002 model years. A requirement of 10 percent ZEVs applied to all but small-volume manufacturers starting in model-year 2003.

In 1996, the CARB modified the regulations to allow supplementary time for new technology to develop. The requirement for 10 percent ZEVs in model years 2003 and beyond was maintained, but the sales requirement for model years 1998 through 2002 was eliminated.

As part of the 1998 "LEV II" rulemaking, the CARB provided additional flexibility in the ZEV program by allowing additional types of vehicles to be used to fill program requirements. Under the 1998 amendments, manufacturers may use partial credits of 0.2 or more generated from vehicles with extremely low emissions (referred to as partial ZEV allowance vehicles or PZEVs) to meet the 10 percent ZEV requirement. However, large-volume manufacturers must, at a minimum, have 4 percent of their California fleet of passenger cars and lightest trucks be vehicles classified as "full" ZEVs [2].

Other aspects of the program provide additional options to manufacturers. Car companies can earn extra ZEV allowances by introducing vehicles before the 2003 model year, thus reducing the total ZEV obligation. Extra allowance is available for $\mathrm{BEV}$ also with more than a 100-mile range per charge. Manufacturers may delay compliance by one year provided they produce two years' worth of ZEVs by the end of the 2004 model year.

Nevertheless, after the 2000 Biennial Review, the Board directed staff to develop and propose regulatory modifications. Following the public hearing on January 25, 2001, the Board adopted Resolution 01-1, in which the Board 
approved amendments to title 13, California Code of Regulations, sections 1962, 1900, 1960.1(k) and 1961. CARB further relaxed the ZEV mandate to allow large-volume manufacturers to meet another $20 \%$ obligation with partial credits from advanced-technology vehicles (AT-PZEVs). Several other refinements and additions to ZEV credit structure were enacted in this same rule-making.

\section{B. Litigation and Settlement}

In June 2002, a California federal judge issued a preliminary injunction against implementation of the ZEV mandate in a lawsuit brought by vehicle manufacturers and dealers. The litigation involves three separate lawsuits in federal and state courts located in Fresno. Those lawsuits challenged the CARB's authority to promulgate the 2001 ZEV regulation. They were based on claims under several state laws, as well as a claim that federal fuel economy laws preempt the $2001 \mathrm{ZEV}$ regulation. The injunction prohibit enforcement of the $2001 \mathrm{ZEV}$ regulation in the 2003 and 2004 MY citing the federal government's role in regulating fuel economy, while the case moved forward on the merits. The preliminary injunction was appealed by CARB to the Federal Ninth Circuit Court of Appeals in San Francisco [3]. While the Court heard the appeal but has not issued an opinion yet in February 2003, a settlement of that litigation in April was made. CARB amended mandate to provide an Alternative Compliance Plan (ACP) in which large-volume manufacturers could meet their $\mathrm{ZEV}$ requirement.

\section{The Following Amendments and Regulatory Activities}

In order to address the preliminary injunction and better align the program requirements with the status of technology development, CARB staff proposed additional modifications to the ZEV regulation in March 2003. In early 2007, the Board determined that staff should recommend changes to the regulation for the 2009 and subsequent model years. The modifications to the regulation approved by the Board at the March 27, 2008 hearing; simultaneously the Board also directed staff to redesign the ZEV Program so it will affect the 2015+ model years. In 2012, the Board adopted Advanced Clean Cars program. On July 10, 2013, the California Secretary of State approved the latest amendments to the California Zero Emission Vehicle (ZEV) regulation which are the three sections of the California Code of Regulations (CCR) that contain requirements for the California $\mathrm{ZEV}$ regulation: (1) CCR Section 1962.1: 2009-2017 Model Year Requirements; (2) CCR Section 1962.2: 2018 and Subsequent Model Year Requirements; (3) CCR Section 1962.3: Electric Vehicle Charger Requirements.

The CARB has been the leader in the development of programs designed to reduce emissions from mobile sources, not only the accomplishments it made but legal methodology it take. As long as mobile sources accounted for well over half of the emissions which contribute to ozone and particulate matter air pollution in California, ZEVs and near-zero emission vehicles are indeed a key element of California's program for attaining health-based air quality standards.

\section{ANALYSIS OF REGULATORY STRATEGY}

California has put in place a unique, comprehensive, and largely coherent set of policies to reduce GHGs and oil use in transportation. Impressively, most of these policies are regulatory. Since the 1977 amendments to the U.S. Clean Air Act, other states have enjoyed the option of following the more stringent California standards instead of the federal standards. The California legislature took advantage of this authority in 2002 when it directed the California Air Resources Board (CARB) to adopt limits on vehicular emissions of greenhouse gases (GHGs). The California strategy departs from the common approach to climate change in two notable ways: It does not depend on international agreements, and although it incorporates market instruments, it relies primarily on performance-based regulatory actions. Both elements are critical to its success. It is a kind of bottom-up model approaches contained in international treaties and even national rules, and also required to achieve substantial climate change mitigation. Such a bottom-up approach that more directly engages individuals and businesses is specially needed in urgent action for environment.

Certainly, a regulatory science driven regulatory strategy is and should be essential as part of today's energy and environmental policies. Regulatory science is the science of developing new tools, standards, and approaches to assess the performance as well as to facilitate technology. Recognizing the success of California model, there are some regulatory strategies which affects participants in the market may need more discussed as follows:

First, the critical challenges of GHGs underscore the importance of modernizing and advancing regulatory science to match zero-emission goal. Clearly for participants including consumers and car manufacturers to realize their full potential for involving public health and new technologies, CARB must be able to issue clear rules, play a major role in the development of electric vehicles, and make sound regulatory decisions about risks and benefits.

To help meet these challenges, and based on the benefits to the economy, environment, and quality of life, California has taken a number of legislative and regulatory steps to promote electric vehicle deployment and adoption, such as the ZEV, Low Carbon Fuel Standard regulatory programs and rebates for purchasing electric vehicles. The Board recently bolstered its vehicle emissions program by creating the Advanced Clean Cars program in 2012. These works builds upon advancing regulatory science, and in these programs, CARB identifies priority areas where new or enhanced investments in regulatory science research capacity will be essential to continued mission success and to public health and safety.

Second, Public-Private Partnership (PPP) models [4] hereby in a broad sense are a key component of the implementation strategy for CARB regulatory science. PPPs are one mechanism that can be used to leverage CARB resources by working collaboratively with both public and private partners, to achieve the agency's mission as well as that of the partners. PPPs may take many forms and can range widely in size and scope. In addition, PPPs provide a means to leverage funds from academic institutions, CARB, other government agencies, and industry to support regulatory science priority areas as defined in this plan [5]. 
CARB collaborates with partners from a wide range of other organizations including, but not limited to, research universities, innovators, entrepreneurs, professional societies, charitable foundations, and academic institutions. Actually, California is home to the world's largest venture capital industry, which favors clean energy policy, as well as a diverse resource base of solar, wind, ocean, and geothermal energy resources. The state's politicians feel freer to pursue aggressive energy and climate policies than do their counterparts in many other states. Thus, the PPPs can be designed around the strategic priorities set forth herein and constructed in ways that advance the regulatory science research efforts of CARB in an efficient and cost-effective manner. Because these partnerships will be science-driven, aimed at advancing regulatory science, and structured to uphold the principles of transparency, fairness, inclusiveness, scientific rigor, and compliance with Federal laws and California policy, they are efficient tools to achieving the Board's mission of advancing regulatory science.

Third, since the requirements of the $\mathrm{ZEV}$ program have resulted in several important milestones being achieved. To ensure the regulatory science remains up to date, CRAB periodically use staff and other outside experts to aid in identifying and prioritizing research efforts and to provide input on the relevance, quality, and productivity of these regulatory programs. Such as at its March 2008 hearing, the Board directed staff to redesign the 2015 and subsequent model year requirements for the ZEV regulation. It directed staff to strengthen the regulation above what is currently required and focus primarily on the zero emission drive, that is BEV, hydrogen FCV, and PHEV technologies. After the hearing, the Board adopted Resolution 09-66, reaffirming its commitment to meeting its long term air quality and GHGs reduction goals through commercialization of $\mathrm{ZEV}$ technologies. The Board further directed to consider shifting the focus of the ZEV regulation to both GHGs and criteria pollutant emission reductions, commercializing ZEVs and PHEVs in order to meet the 2050 goals, and to take into consideration the new Low Emission Vehicle (LEV III) fleet standards and propose revisions to the $\mathrm{ZEV}$ regulation accordingly.

The goal of the Board direction was to ensure California as the central location for moving advanced, low GHGs technology vehicles from the demonstration phase to commercialization. This California rulemaking is a successful regulatory science program to commit to the transformation of California light-duty vehicle fleet. Translating key findings into $\mathrm{CRAB}$ regulations, such as the technology-forcing piece of the Advanced Clean Car package, the ZEV regulation along with new LEV III criteria pollutant and GHG standards can be the catalyst to that transformative process. For reflecting the latest understanding, proposed amendments to the regulation focus on technologies that help meet long term emission reduction goals, simplify the program where needed, and increase requirements for 2018 and subsequent model years [6].

The sections above briefly describe some of California avenues for fostering a strong regulatory science culture. It did improve the scientific infrastructure, and promote and engage in the regulatory activities agenda laid out in

\section{California plan.}

\section{GLOBAL OVERVIEW OF REGULATORY LANDSCAPE}

The United Nations Economic and Social Council (UN ECOSOC) adopted a Proposal for an Electric Vehicle Regulatory Reference Guide in 2014. According to the global picture of EV regulatory methodology, there are six main subsections concerning regulatory infrastructure of electric vehicle market deployment $(A$.) and vehicle itself $(B . \sim F$.):

\section{A. Regulatory Incentives}

The so called legal requirements contain an incentive for deployment of electrified vehicles. The term 'legal requirements' is broad and can refer to any regulation, legislation, code, and/or standard that is rooted in law. In general, regulatory incentives are widely available throughout the world. In the EU, regulation 443/2009/EC establishes fleet-wide $\mathrm{CO}_{2}$ targets that include electrified vehicles. Specifically, super-credits are available to manufacturers for any of their vehicles that emit less than $50 \mathrm{~g} / \mathrm{km}$ of $\mathrm{CO}_{2}$ in the years 2013 to 2015 and 2020 to 2022 to encourage more of the cleanest vehicles into the European market. Canada's current GHGs emission regulations for new cars and trucks aim to reduce GHGs emissions from vehicles by establishing mandatory GHGs emission standards in alignment with U.S. standards. The regulations include additional flexibilities for advanced technologies, like hybrid and electrified vehicles, which encourage vehicle manufacturers to adopt low GHGs emission technology. China has established a Corporate Average Fuel Consumption (CAFC) law which specifies standards, methods and regulatory incentives for PEVs, FCVs, and OVC-HEVs with electric driving ranges greater than $50 \mathrm{~km}$ as well as for so-called low fuel consumption vehicles (lower than $2.8 \mathrm{~L} / 100 \mathrm{~km}$ ). The corresponding rules pertaining to credits and penalties are under development.

Japan is said to award credits to manufacturers for the sale of PEVs and OVC-HEVs, in accordance with its 2020 fuel economy standard. Switzerland has adopted the previously cited EU regulations into Swiss law. South Korea regards pure electric vehicles as zero $\mathrm{CO}_{2}$ vehicles and awards super credits to vehicles emitting less than $50 \mathrm{~g} / \mathrm{km}$ of $\mathrm{CO}_{2}$, in accordance with its national light-duty vehicle fuel economy and GHGs regulations.

In the US, Environmental Protection Agency (EPA) / the National Highway Traffic Safety Administration (NHTSA) provides a zero tailpipe emission score and bonus credits to electrified vehicles up to a specific cap under the national light duty vehicle GHGs emissions regulations. The California zero emission vehicle (ZEV) mandates requires sales percentages of plug-in and fuel cell passenger vehicles to 2025. Credits are based on vehicle type (pure ZEV or plug-in hybrid) and ZEV range. Pure battery electric, fuel cell electric and plug-in hybrids are eligible for credits. California also has a passenger vehicle fleet average GHGs standard that is coordinated with the federal GHGs standards, and electrified vehicles can earn credits towards the GHGs fleet average standards. The California program has also been adopted by several other states. High Occupancy Vehicle/High Occupancy Toll lane exemptions are provided 
to HEVs by many US states to encourage adoption of the technology. The following states presently offer these exemptions: Arizona, California, Colorado, Florida, Georgia, Hawaii, Maryland, North Carolina, New Jersey, New York, Tennessee, Utah, and Virginia.

From a market deployment standpoint, the area of regulatory incentives was also found to be at a high state of activity (Fig. 1).

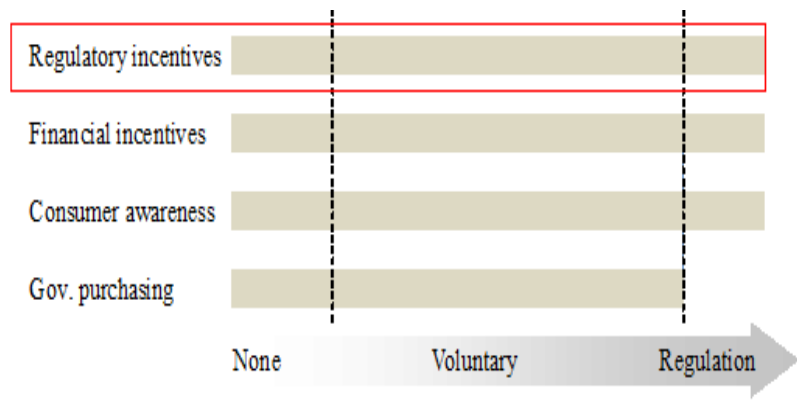

Source: UNECE Electric Vehicle Regulatory Reference Guide (2014) Fig. 1. Activity chart, market deployment attributes.

\section{B. Electric Range}

Electrified vehicle range is widely regulated. The European Union and Switzerland determine range in accordance with UN Regulation No. 101 (UN-R 101), respect to light duty motor vehicles and has custom-tailored these electric range requirements for L-category vehicles. A memorandum of understanding is in place between the Government of Canada and industry for the purposes of vehicle labeling only, which involves range determination. China has a voluntary Chinese National Standard that is available for adherence to $(\mathrm{GB} / \mathrm{T}$ 18386-2005), which is quoted in the regulation 'Management Rules for New Energy Vehicle Production Enterprises and Product Access', and thus recognized as mandatory.

Japan specifies its own test procedure based on the JC08 dynamometer test cycle (TRIAS 99-011-01). South Korea employs a procedure similar to that of the US EPA/NHTSA (described below).

The SAE J1634 recommended practice has been adopted as the test procedure for the US EPA/NHTSA. Distinctively, the CARB has its own range test procedure employed in determination of allowance credits in connection with its Zero Emission Vehicle (ZEV) Regulation.

\section{Energy Consumption/Efficiency}

The EU and Switzerland regulate EV energy consumption through the test procedure outlined in UN-R 101. Canada does not presently have in place any requirements relating to electrified vehicle energy consumption/efficiency. There are voluntary Chinese National Standards pertaining to energy efficiency of EVs (GB/T 18386-2005) and HEVs (GB/T 19753-2005), which have been subsequently recognized as mandatory.

Japan specifies its own test procedure based on the JC08 dynamometer test cycle (TRIAS 99-011-01). South Korea has adopted the same requirements specified by the US EPA/NHTSA.

The US EPA/NHTSA require that electrified vehicle energy consumption be determined in accordance to SAE J1634 (PEV), J1711 (NOVC-HEV and including OVC-HEV) and J2841 (- Utility Factor Definitions for OVC-HEV). California does not have separate requirements for energy consumption and is generally aligned with the preceding US Federal regulations.

\section{Electrified Vehicle Driver-User Information}

Driver-user information is an attribute that is largely lacking any formal regulation globally at the present time. China has a voluntary Chinese National Standard GB/T 4094.2-2005 that specifies EV-specific symbols relating to controls, indicators and tell-tales. This standard is quoted in regulation 'Management Rules for New Energy Vehicle Production Enterprises and Product Access', and is thus now recognized as mandatory. With the same method, Japan has voluntary standards for EV driver-user information (JEVS Z 804-1998).

\section{E. Electrified Vehicle Recycling and Re-use}

The European Union regulates M1 and N1 type vehicle [7] recycling through its Directive on End-of-Life Vehicles (2000/53/EC). Directive 2005/64/EC is a subsequent law that further stipulates the degree of recyclability, reusability and recoverability required for $\mathrm{M} 1$ and $\mathrm{N} 1$ vehicles prior to their approval for sale in the EU. Dissimilarly, Canada employs a voluntary code of conduct to guide recyclers knows as the Canadian Auto Recyclers' Environmental Code (CAREC). China has a mandatory Chinese National Standard that governs vehicle end-of-life recycling and dismantling (GB 22128-2008).

Japan governs vehicle recycling through Act No. 87 of the Ministry of Economy, Trade and Industry (Act on Recycling, etc. of End-of-Life Vehicles). South Korea stipulates requirements for vehicle recycling through Act No. 11913, managed by the Ministry of Environment.

Swiss federal regulations for recycling are based on EC Directive 2000/53/EC mentioned previously. The US does not presently have any federal requirements that govern vehicle recycling. It should be noted that in addition to governing the recycling of vehicles, Japan and Korea have laws that require vehicle manufacturers to pro-actively emphasize recyclability in the design and manufacture of their products.

\section{F. Vehicle Labeling}

The EU employs a fuel economy label that provides fuel consumption, annual operating cost, and $\mathrm{CO}_{2}$ emissions for light duty motor vehicles. In the EU this labeling scheme is not yet applicable to L-category vehicles but vehicle manufacturers are required to ensure that the $\mathrm{CO}_{2}$ emission, fuel consumption, electric energy consumption and electric range data are provided to the buyer of the vehicle at the time of purchase of a new vehicle, in a format which they consider appropriate. $\mathrm{CO}_{2}$ emissions are ranked using an alphabetized grade (A-G) system. Emissions of vehicles determine in turn, the level of Vehicle Circulation Tax imposed for usage of the vehicle.

A memorandum of understanding is in place between the Government of Canada and industry for the purposes of vehicle labeling. China's light vehicle labeling requirements are captured in a mandatory National Standard (GB 
22757-2008). The label features three fuel economy ratings covering urban, suburban driving conditions and a composite of the two referred to as 'integrated operating condition.' This label only applies to vehicles equipped with conventional internal combustion engine powertrains and will extend to electrified vehicles in the near future.

Japan has voluntary fuel economy performance stickers that can be affixed to vehicles that meet or exceed fuel economy standards. These labels indicate that the vehicles bearing them are eligible for fiscal incentives only and do not provide any specifications or actual statement of fuel consumption. There is no label available for PEVs, OVC-HEVs, or vehicles featuring natural gas or clean diesel power trains, despite these vehicles being included under the same fiscal incentive scheme. South Korea introduced fuel economy labels according to the 'Energy Use Rationalization Act' in 1989, and improved the label scheme extensively with the new fuel economy adjusted by the 5-cycle formula to reflect real-world driving conditions as done in the US in 2011. The values on the label represent the performance of the vehicle in terms of the fuel economy values. All the vehicles with gross vehicle weight of 3.5 tons or less have to be given the grade except PEVs and compact cars with a displacement of $1,000 \mathrm{cc}$ or less.

Switzerland requires labels indicating fuel consumption, $\mathrm{CO}_{2}$ emissions, and a letter grade between (A-G) denoting performances in fuel economy; $\mathrm{A}$ indicates the lowest consuming vehicle and $\mathrm{G}$ the highest, where the indication from $A$ to $G$ is segment specific by considering inter alia the vehicle curb weight. The US EPA employs a series of 'fuel economy and environment' labels that address conventional gasoline/diesel powered vehicles, flex-fuel vehicles, CNG vehicles, OVC-HEVs (both series and blended4), PEVs, and hydrogen FCVs; the label is not segment specific, in that it applies to all light duty vehicles. Labels include fuel economy information, as well as GHGs and smog ratings based on a relative scale of 1 to 10 . Alternative fuel and electrified vehicles feature gasoline equivalent MPG (so-called MPGe) ratings to facilitate comparison activity as well as a statement of range attainable on a single tank of fuel and/or a single full charge of the on-board battery pack.

In general the presence of requirements in the surveyed countries was high with respect to vehicle-level attributes, with the exception of driver-user information which was largely absent across some countries. This is illustrated in Fig. 2 .

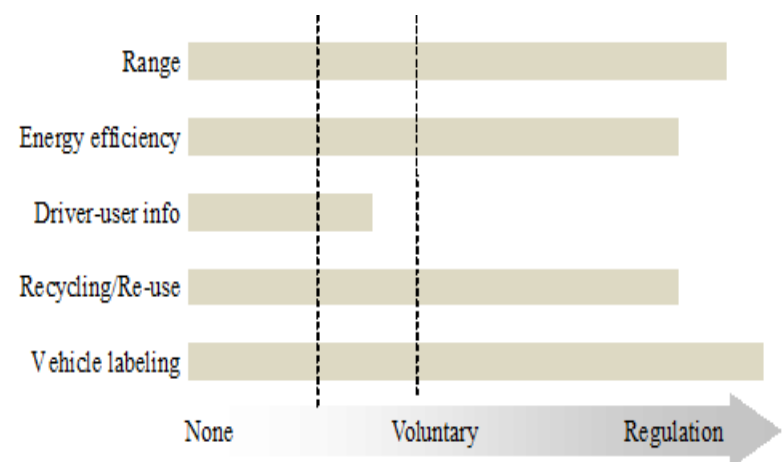

Source: UNECE Electric Vehicle Regulatory Reference Guide (2014) Fig. 2. Activity chart, vehicle attributes.
Though these charts employ a simple scoring system where responses of no requirements are assigned a numerical value of 0 , voluntary requirements are assigned a value of 1 , and legislated requirements are assigned a value of 2 . It still provides an overview of the overall level of activity by attribute, for electrified vehicle requirements. Comparing the global regulatory landscape with California model, we may conclude that regulatory and legal strategies do be emphasized as significant tool to meet the goal of reduce GHGs emission. California chooses a right way; especially the Zero Emission Vehicle Program mandates directly require sales percentages of plug-in and fuel cell passenger vehicles that lots of countries never do. Although many experts say that the solution to our energy and climate problems is sending the correct price signals to industry and consumers, the transport sector's behavior is highly inelastic in that it does not change significantly in response to changes in fuel prices, at least in the range that is politically acceptable. High fuel taxes certainly have an effect in reducing the average size and power of vehicles and leading people to drive less, but the resulting reductions in fuel use and GHGs still fall far short of the climate goals.

\section{CONCLUSION}

It seems no gaps that exist in the context of regulatory incentives. Yet, on global regulatory landscape, vehicle-level attributes do feature some gaps, despite their high global activity level. The California strategy departs from the nation wild common approach to climate change in two notable ways: It become independent from international agreements, although it incorporates market instruments, it relies primarily on performance-based regulatory actions. Further, even car companies filed lawsuits against California and states that followed California's lead. When those lawsuits failed, the Bush administration refused to grant a waiver to California to proceed, even though waivers were granted routinely for previous vehicle emissions regulations by California. In 2009, President Obama not only agreed to grant a waiver, but committed the entire country to the aggressive California standards. With the decision to grant the California waiver, EPA returns to its traditional legal interpretation of the Clean Air Act that has been applied consistently during the past 40 years. EPA finds that California continues to have a need for its motor vehicle emissions program, including the greenhouse gas standards. EPA also finds that the California program meets legal requirements regarding the protectiveness of public health and welfare as well as technological feasibility.

Although some once consider the California ZEV mandate a policy failure, since the ZEV rules are multiply adjusted after surviving industry litigation. However, from the viewpoint of regulatory science, appropriate adjustment to reflect the uneven progress of hybrid, fuel cell, and battery technologies is absolutely necessary. In other words, decoupling is a positive trend, and replacing the current decoupling policy with a modified regulatory structure is smart.

For regulatory thinking, the purpose to impose burden or 
obligation on those who operate enterprises certainly should be justified. California's regulatory structure ensures that state consumers receive ever-cleaner energy and focus on efficiency instead of supply generation only. In addition, it emphasizes the facilitation of a variety of techniques and technologies, including energy storage technologies like batteries, let alone this California model has the benefit of minimal cost to taxpayers, extensive use of performance-based standards, and some harnessing of market forces. Given that the statutory provision in question carries a legitimate purpose and the means taken are also necessary to achieve those objectives, the provision is in compliance with the principle of proportionality set forth in the Constitution, and does not contradict the other statutory provisions.

\section{REFERENCES}

[1] The California Air Resources Board. (October 2014). Zero-Emission Vehicle Legal and Regulatory Activities and Background. [Online]. Available:

http://www.arb.ca.gov/msprog/zevprog/zevregs/zevregs.htm

[2] The California Air Resources Board. (January 2001). Notice of Public Hearing to Consider Amendments to the California Zero-Emission Vehicle Regulations. [Online]. Available: http://www.arb.ca.gov/regact/zev2001/Notice1.htm

[3] R. Hagman, TØI and E. S. Civitas, Environmentally Friendly Vehicles: Experiences and Definitions, Nordic Council of Ministers, Copenhagen, pp. 66-68, 2007.

[4] United Nations Economic and Social Commission for Asia and the Pacific (ESCAP), A Guidebook on Public-Private Partnership in Infrastructure, Bangkok, 2011, ch. 1, pp. 1-12.
[5] A legal and regulatory framework that supports PPPs includes facilitating investments, long-term PPP arrangements, reducing transaction costs, ensuring appropriate regulatory controls, and providing legal and economic mechanisms to enable the resolution of contract disputes. The design of PPP legal frameworks though varies across EU countries depends on legal tradition and existing laws. See EU the Public Sector Directive (2004/18/EC), and the Utilities Directive (2004/17/EC). Also see OECD (2008), Transport Infrastructure Investments: Options for Efficiency; United Nations Commission on International Trade Law (2004), Model Legislative Provisions on Privately Financed Infrastructure Projects.

[6] California Environmental Protection Agency Air Resources Board, Staff Report: Initial Statement of Reasons Advanced Clean Cars 2012 Proposed Amendments to the California Zero Emission Vehicle Program Regulations. (December 2011). ES-1 and 2. [Online]. Available: http://www.arb.ca.gov/regact/2012/zev2012/zevisor.pdf

[7] M1 and N1 vehicles are defined according to Directive 70/156/EEC as follows: Category M1- Vehicles designed and constructed for the carriage of passengers and comprising no more than eight seats in addition to the driver's seat. Category N1- Vehicles designed and constructed for the carriage of goods and having a maximum mass not exceeding 3.5 tonnes.

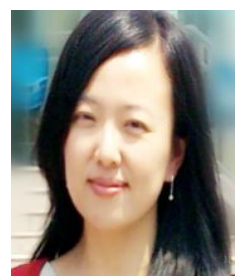

Ju-Yin Chen was born in 1975, graduated in law in 1997 and obtained her M.L. degree in law in 1999 from National Taipei University, Taipei, Taiwan. She completed her Ph.D. in law from Soochow University, Taiwan in 2008. She is currently an associate professor at the Department of Law from Soochow University and also teaches at the graduate and undergraduate courses in civil law, contract, and consumer protection laws. Her research interests include energy law centered on consumer choice, contract, and policy. 